\title{
Marinitoga okinawensis sp. nov., a novel thermophilic and anaerobic heterotroph isolated from a deep-sea hydrothermal field, Southern Okinawa Trough
}

\author{
Takuro Nunoura, Hanako Oida, Masayuki Miyazaki, Yohey Suzuki, \\ Ken Takai and Koki Horikoshi
}

Correspondence

Takuro Nunoura

takuron@jamstec.go.jp

\begin{abstract}
Subground Animalcule Retrieval (SUGAR) Program, Extremobiosphere Research Center, Japan Agency for Marine-Earth Science \& Technology (JAMSTEC), 2-15 Natsushima-cho, Yokosuka 237-0061, Japan
\end{abstract}

The order Thermotogales is composed of six genera: Thermotoga, Thermosipho, Fervidobacterium, Petrotoga, Geotoga and Marinitoga. Members of these genera have been isolated from a variety of high temperature environments such as deep-sea hydrothermal vents, hot springs and oil reservoirs. All of these organisms are thermophilic or hyperthermophilic chemo-organotrophs, but do not utilize hydrogen or other inorganic compounds as electron donors (Davey et al., 1993; Huber et al., 1986, 1989; Patel et al., 1985; Wery et al., 2001). In the genus Marinitoga, three thermophilic chemo-organotrophs that have optimum temperatures for growth of between 55 and $65^{\circ} \mathrm{C}$ have been isolated from deep-sea hydrothermal vents and characterized. Marinitoga camini (Wery et al., 2001), the type species of this genus, was isolated from the MidAtlantic Ridge (MAR). The other two recognized species in the genus, Marinitoga piezophila (Alain et al., 2002) and Marinitoga hydrogenitolerans (Postec et al., 2005) were isolated from the East-Pacific Rise (EPR) and MAR,

Abbreviations: EPR, East-Pacific Rise; MAR, Mid-Atlantic Ridge.

The GenBank/EMBL/DDBJ accession number for the 16S rRNA gene sequence of strain TFS10-5 $5^{\top}$ is AB262395.

Graphs showing the effects of temperature, $\mathrm{pH}$ and $\mathrm{NaCl}$ concentration on the growth of strain TFS $10-5^{\top}$ are available as a supplementary figure in IJSEM Online. respectively. A difference in hydrogen tolerance has been observed among these three species. M. camini and $M$. piezophila are strongly inhibited by hydrogen in the absence of sulfur but are able to grow under hydrogen in the presence of sulfur (Alain et al., 2002; Wery et al., 2001). M. hydrogenitolerans is able to grow in the presence of hydrogen even in the absence of sulfur (Postec et al., 2005). In this study, we isolated and characterized a novel thermophilic bacterium which belongs to the genus Marinitoga and can grow under $100 \%$ hydrogen in the absence of sulfur.

A large piece of sulfide flange from a black smoker chimney on the Tiger chimney mound $\left(24^{\circ} 50.938^{\prime} \mathrm{N} 122^{\circ} 42.020^{\prime} \mathrm{E}\right)$ in the Yonaguni Knoll IV, Southern Okinawa Trough, was obtained with the manned submersible Shinkai 6500 during the cruise YK03-05 (July 2003) of the R/V Yokosuka. The main vent emission of this black smoker contained $0.8 \mathrm{mM}$ $\mathrm{H}_{2} \mathrm{~kg}^{-1}, 1.8 \mathrm{mM} \mathrm{CH}_{4} \mathrm{~kg}^{-1}$ and $72 \mathrm{mM} \mathrm{CO}_{2} \mathrm{~kg}^{-1}$ (Konno et al., 2006) and the maximum temperature was $330^{\circ} \mathrm{C}$ but the geochemistry and temperature of the fluids under the flange structure were not determined. Subsamples were taken of the surface layer and orifice of the sulfide structure of the chimney structure as described previously (Takai et al., 2001) and these were stored anaerobically (with or without $0.05 \%$ neutralized $\mathrm{Na}_{2} \mathrm{~S}$ ) in glass bottles under an atmo- 
sphere of $100 \% \mathrm{~N}_{2}(200 \mathrm{kPa})$ and sealed with butyl rubber stoppers for cultivation. The subsamples were used for serial dilution cultivation tests using various media. Using MMJYPS medium, consisting of MJ synthetic seawater (Sako et al., 1996), $0.1 \%$ yeast extract (Difco), $0.1 \%$ tryptone peptone (Difco) and $0.3 \%$ sulfur, at a pH adjusted to around 5.5 and with a head space gas mixture of $80 \%$ $\mathrm{H}_{2}: 20 \% \mathrm{CO}_{2}(200 \mathrm{kPa})$ and an incubation temperature of $55^{\circ} \mathrm{C}$, growth of thin rods was observed from the most diluted series $\left(<2.0 \times 10^{5}\right.$ cells $\left.^{-1}\right)$ and thick rods from the second-most diluted series $\left(<2.0 \times 10^{4}\right.$ cells $\left.^{-1}\right)$ in jars inoculated with samples from the surface of the sulfide flange structure. Pure cultures of both thin and thick rods were obtained by performing a dilution to extinction procedure three times at $55^{\circ} \mathrm{C}$. When the purity of the isolates was tested by microscopic observations, it was apparent that the thin rods were members of the D subgroup of the Epsilonproteobacteria (Lebetimonas sp.) (data not shown). The thick rods were found to belong to the genus Marinitoga by partial sequencing of the $16 \mathrm{~S}$ rRNA gene. The thick rod culture was further purified by the dilution to extinction technique (Takai et al., 2000) and strain TFS10$5^{\mathrm{T}}$ was obtained.

Since the growth of chemolithoautotrophs such as Lebetimonas acidophila (Takai et al., 2005) would also be expected in MMJYPS medium as well as growth of chemoorganotrophs and chemolitho-organotrophs, the utilization of possible electron donors $\left(\mathrm{H}_{2}\right.$, yeast extract and tryptone peptone) and acceptors (sulfur, thiosulfate, sulfate, sulfite, L-cystine, nitrate, nitrite and $\mathrm{O}_{2}$ ) was examined for strain TFS $10-5^{\mathrm{T}}$. No differences in growth rate or final cell concentration $\left(2.0 \times 10^{8}\right.$ cells ml $\left.^{-1}\right)$ were found with samples grown under $80 \% \mathrm{H}_{2}: 20 \% \mathrm{CO}_{2}$ and $80 \% \mathrm{~N}_{2}: 20 \% \mathrm{CO}_{2}$ in the presence of yeast extract, tryptone peptone or elemental sulfur. No growth occurred under any autotrophic conditions. The results indicate that the novel isolate does not use $\mathrm{H}_{2}$ as an electron donor and is not sensitive to $\mathrm{H}_{2}$ in the presence of sulfur. In the absence of electron acceptors, strain TFS $10-5^{\mathrm{T}}$ could grow by fermentation, but the final cell concentration was 10 -fold lower than that recorded in the presence of elemental sulfur $\left(2.0 \times 10^{7} \mathrm{cells} \mathrm{ml}^{-1}\right)$ under $80 \% \mathrm{~N}_{2}: 20 \% \mathrm{CO}_{2}$. Only slight suppression of

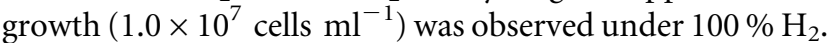
Isolate TFS $10-5^{\mathrm{T}}$ utilized elemental sulfur and L-cystine as electron acceptors and reduced them to $\mathrm{H}_{2} \mathrm{~S}$. The isolate was very sensitive to oxygen and could not grow in medium even slightly coloured by resazurin.

Cells were routinely observed with a light microscope (BX51; Olympus). Transmission electron microscopy (TEM) with negatively stained cells was performed as described by Zillig et al. (1990). Cells grown in MMJYPS medium at $55{ }^{\circ} \mathrm{C}$ in the late exponential growth phase were used for TEM observations. Cells of strain TFS10 $-5^{\mathrm{T}}$ were straight rods, about $1.5-5 \mu \mathrm{m}$ in length, $0.5-0.8 \mu \mathrm{m}$ in width and motile with a polar flagellum. Negatively stained cells showed a thick outer membrane (Fig. 1).

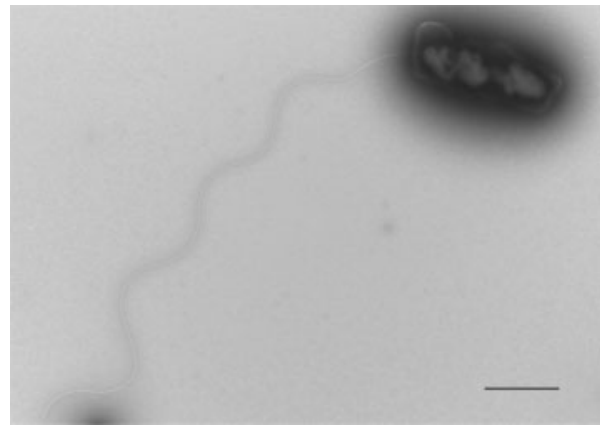

Fig. 1. Electron micrograph of a negatively stained cell of strain TFS $10-5^{\top}$. Bar, $1 \mu \mathrm{m}$.

Growth of the novel isolate was determined by direct cell counting under epifluorescence after staining with $4^{\prime}$, 6-diamidino-2-phenylindole (DAPI) (Porter \& Feig, 1980) using an Olympus BX51 microscope. To determine the range of temperature, $\mathrm{pH}$ and $\mathrm{NaCl}$ concentration for growth, the cultures were grown in $15 \mathrm{ml}$ test tubes containing $3 \mathrm{ml}$ MMJYPS medium with shaking (100 r.p.m.) in a temperature-controlled drying oven. Strain TFS $10-5^{\mathrm{T}}$ grew over the temperature range of $30-70{ }^{\circ} \mathrm{C}$ and the optimum temperature for growth was $55-60{ }^{\circ} \mathrm{C}$. The doubling time at the optimum temperature was $0.8 \mathrm{~h}$ and

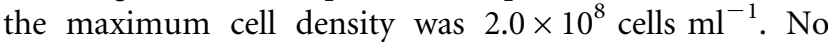
growth was observed at 25 or $75^{\circ} \mathrm{C}$. The effect of initial pH on growth was examined at $55^{\circ} \mathrm{C}$ using MMJYPS medium adjusted to various $\mathrm{pH}$ values as described previously (Takai et al., 2005). The $\mathrm{pH}$ range for growth was 5.0-7.4 and the optimum $\mathrm{pH}$ was 5.5-5.8. The optimum $\mathrm{NaCl}$ concentration for growth in MMJYPS medium was also tested and growth was observed at $\mathrm{NaCl}$ concentrations of between 1.0 and $5.5 \%(\mathrm{w} / \mathrm{v})$; the optimum concentration range was $3.0-3.5 \% \mathrm{NaCl}$ (see Supplementary Fig. S1 in IJSEM Online).

The utilization of carbon sources was tested at $55^{\circ} \mathrm{C}$ using MMJYPS medium without yeast extract and tryptone peptone but supplemented with a vitamin mixture (Balch et al., 1979) and the following carbon sources: yeast extract, tryptone peptone, peptone, Casamino acids (Difco), gelatin, chitin, starch, glucose, fructose, maltose, galactose, lactose, cellobiose, xylose, sucrose, rhamnose, mannose, ethanol, methanol, glycerol, acetate, propionate, pyruvate, formate, fumarate, citrate, malate, succinate, tartrate, glutamate, glycine, alanine and xylan. Each substrate was tested at concentrations of $0.01 \%$ and $0.1 \%$. Strain TFS $10-5^{\mathrm{T}}$ was only able to utilize proteinaceous complex substrates such as yeast extract, tryptone peptone and peptone. In order to test the utilization of carbon sources other than proteinaceous complex substrates, the substrates mentioned above were supplemented with $0.02 \%$ yeast extract. Growth with each substrate was compared with growth in a medium that contained $0.02 \%$ yeast extract with minerals. Starch, glucose and glycerol improved growth of strain TFS $10-5^{\mathrm{T}}$ when 
Table 1. Comparison of characteristics of members of the genus Marinitoga

Strains/species: 1 , TFS10 $-5^{\mathrm{T}}$ (data from this study); 2, M. camini MV1075 ${ }^{\mathrm{T}}$ (Wery et al., 2001); 3, M. piezophila KA3 ${ }^{\mathrm{T}}$ (Alain et al., 2002); 4, M. hydrogenitolerans AT1271 ${ }^{\mathrm{T}}$ (Postec et al., 2005). Substrates were tested in the presence of yeast extract $\left(0.1 \mathrm{~g} 1^{-1}\right.$ for M. camini and M. hydrogenitolerans; $0.2 \mathrm{~g}^{-1}$ for M. piezophila and strain TFS10-5 ${ }^{\mathrm{T}}$. MAR, Mid-Atlantic Ridge; EPR, East-Pacific Rise; SOT, Southern Okinawa Trough. +, Positive; -, negative; $(+)$, weakly positive; ND, not determined.

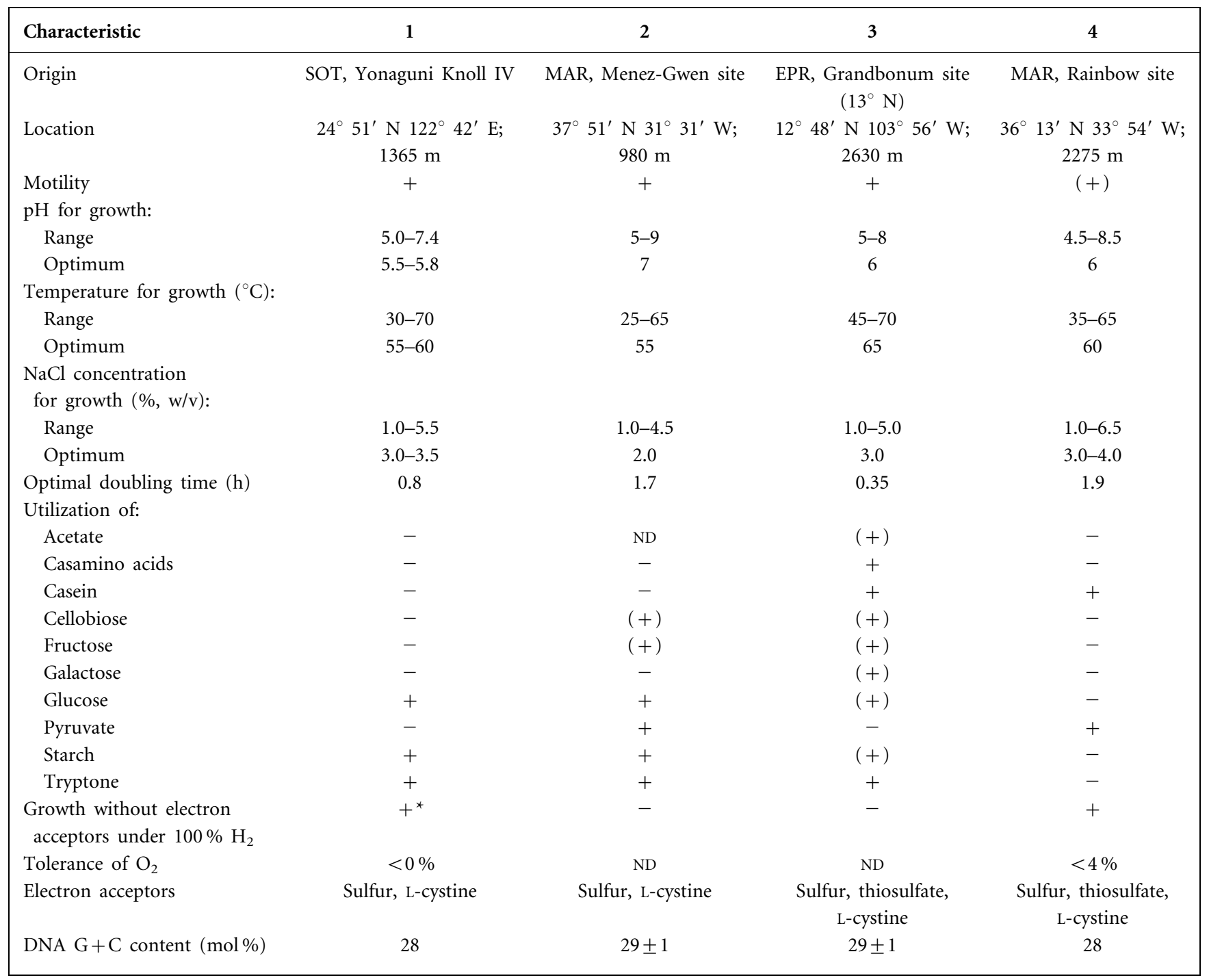

*Slight inhibition was observed.

combined with $0.02 \%$ yeast extract, but other substrates did not support growth even when supplemented with yeast extract.

The cellular fatty acid content of cells of strain TFS10 $-5^{\mathrm{T}}$ was analysed with cells grown in MMJYPS medium at $55^{\circ} \mathrm{C}$ in the late exponential phase. The fatty acid extraction and analysis methods used were as described previously (Takai et al., 2003). The fatty acid content was $\mathrm{C}_{16: 0}(71.0 \%)$, $\mathrm{C}_{16: 1}(6.0 \%), \mathrm{C}_{18: 0}(21.4 \%)$ and $\mathrm{C}_{18: 1}(1.6 \%)$.

The sensitivity of the novel strain to various antibiotics was tested at $55^{\circ} \mathrm{C}$. Growth was inhibited by ampicillin, chloramphenicol, erythromycin, penicillin G, novobiocin, vancomycin and rifampicin at concentrations of $25 \mu \mathrm{g} \mathrm{ml}-1$ and by tetracycline at $100 \mu \mathrm{g} \mathrm{ml}^{-1}$. Strain TFS10-5 ${ }^{\mathrm{T}}$ was resistant to kanamycin, streptomycin and spectinomycin at $100 \mu \mathrm{g} \mathrm{ml}^{-1}$.

Genomic DNA was prepared as described by Lauerer et al. (1986). The G $+\mathrm{C}$ content of genomic DNA was determined by direct analysis of deoxyribonucleotides by HPLC (Tamaoka \& Komagata, 1984). The G+C content of strain TFS $10-5^{\mathrm{T}}$ was $28 \mathrm{~mol} \%$ and this value is similar to that found previously for recognized species of the genus Marinitoga (Table 1). 
The 16S rRNA gene of strain TFS10-5 $5^{\mathrm{T}}$ was amplified by PCR using primers Bac27F and 1492R (DeLong, 1992; Lane, 1991). The sequence of about $1.5 \mathrm{~kb}$ of amplified fragment was determined directly by the deoxynucleotide chaintermination method with a DNA sequencer (model 3100; Perkin Elmer/Applied Biosystems). The almost complete $16 \mathrm{~S}$ rRNA gene sequence (1476 bp) was analysed by the FASTA algorithm (http://www.ddbj.nig.ac.jp/search/fastaj.html). The most similar gene sequences to strain TFS10$5^{\mathrm{T}}$ were those of M. hydrogenitolerans and M. camini $(95.8 \%$ similarity), species that were isolated from the Menez-Gwen and Rainbow sites, respectively, on the MAR (Postec et al., 2005; Wery et al., 2001). The next most closely related sequence was that of $M$. piezophila ( $95.3 \%$ similarity), a species isolated from the Grandbonum site on EPR $\left(13^{\circ} \mathrm{N}\right)$ (Alain et al., 2002). A phylogenetic analysis based on $16 \mathrm{~S}$ rRNA gene sequences clearly showed that strain TFS10-5 ${ }^{\mathrm{T}}$ belonged to genus Marinitoga and the most closely related organism was M. piezophila (Fig. 2).

The characteristics of strain $\mathrm{TFS} 10-5^{\mathrm{T}}$, such as the temperature, $\mathrm{pH}$ and $\mathrm{NaCl}$ concentration for growth, the utilization of proteinaceous complex substrates and reduction of elemental sulfur and L-cystine, are consistent with those of the previously characterized species of the genus Marinitoga. However, several differences were observed between them (Table 1). In terms of oxygen sensitivity, strain TFS $10-5^{\mathrm{T}}$ requires strict anaerobic conditions for growth and so is different from $M$. hydrogenitolerans, which can survive with up to $4 \%$ oxygen in the head space gas (Postec et al., 2005). On the other hand, with regard to the ability to grow under a head space gas of $100 \% \mathrm{H}_{2}$ in the

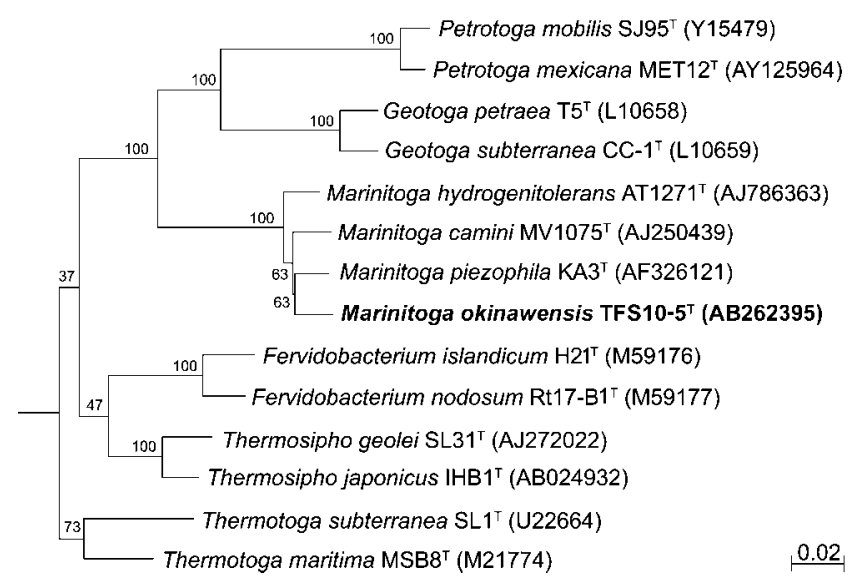

Fig. 2. Phylogenetic tree of species of the order Thermotogales based on 16S rRNA gene sequences constructed by the neighbour-joining method using 1050 homologous sequence positions for each organism. Numbers at nodes indicate bootstrap values from 100 replications. GenBank accession numbers are given in parentheses. Bar, 2 substitutions per 100 nucleotides. absence of electron acceptors (Postec et al., 2005), the new isolate differs from M. camini and M. piezophila (Alain et al., 2002; Wery et al., 2001), but is similar to M. hydrogenitolerans. Fermentative growth of M. camini and M. piezophila does not occur under head space gas concentrations of 40 and $60 \% \mathrm{H}_{2}$, respectively, whereas strain $\mathrm{TFS} 10-5^{\mathrm{T}}$ can grow under $100 \% \mathrm{H}_{2}$ with only slight inhibition and the fermentation of $M$. hydrogenitolerans is not sensitive to hydrogen (Postec et al., 2005) (Table 1). The sensitivity to hydrogen among Marinitoga species is consistent with the hydrogen concentrations found in their respective habitats. The hydrogen contents of the vent emissions at the Rainbow site on MAR and the Yonaguni Knoll IV, from where $M$. hydrogenitolerans and strain TFS10 $-5^{\mathrm{T}}$ were collected, are extraordinary high at 13 and $0.8-5.5 \mathrm{mmol} \mathrm{kg}^{-1}$, respectively (Donval et al., 1997; Konno et al., 2006). The hydrogen concentrations of the Menez Gwen site on MAR and $13^{\circ} \mathrm{N}$ on EPR, from where M. camini and M. piezophila were isolated, are 44 and $143 \mu \mathrm{mol} \mathrm{kg}{ }^{-1}$, respectively (Charlou et al., 1996, 2000). In fact, Marinitoga species may acquire tolerance to hydrogen after inhabiting a hydrogen-enriched hydrothermal field. Given the low levels of 16S rRNA gene sequence similarity between strain TFS $10-5^{\mathrm{T}}$ and the other recognized Marinitoga species and the differences in physiological features (Table 1), the new strain represents a novel species of the genus Marinitoga for which the name Marinitoga okinawensis is proposed.

\section{Description of Marinitoga okinawensis sp. nov.}

Marinitoga okinawensis (o.ki.na.wen'sis. N.L. fem. adj. okinawensis of Okinawa, a region of Japan).

Cells are rod-shaped and motile with polar flagella. Growth occurs at $30-70^{\circ} \mathrm{C}$ (optimum temperature is $55-60{ }^{\circ} \mathrm{C}$ ), at $\mathrm{pH} 5.0-7.4$ (optimum of $\mathrm{pH} 5.5-5.8$ ) and at $\mathrm{NaCl}$ concentrations of $1.0-5.5 \%$ (optimum of $3.0-3.5 \%$ ). The doubling time under optimum conditions is $0.8 \mathrm{~h}$ and cell concentrations reach $2.0 \times 10^{8}$ cells ml $^{-1}$. Obligately anaerobic. Not sensitive to hydrogen in the presence of sulfur; fermentation is suppressed, but not completely inhibited by hydrogen. Obligately chemo-organotrophic. Grows with proteinaceous complex compounds such as yeast extract, tryptone peptone and peptone. Several carbohydrates, starch, glucose and glycerol, also support growth with yeast extract. Growth is greatly enhanced by the addition of sulfur and L-cystine. The fatty acid content is $\mathrm{C}_{16: 0}(71.0 \%), \mathrm{C}_{16: 1}(6.0 \%), \mathrm{C}_{18: 0}(21.4 \%)$ and $\mathrm{C}_{18: 1}$ $(1.6 \%)$. The $\mathrm{G}+\mathrm{C}$ content of genomic DNA is $28 \mathrm{~mol} \%$ (HPLC). 16S rRNA gene sequence analysis indicates that strain TFS10 $-5^{\mathrm{T}}$ is a member of the genus Marinitoga of the order Thermotogales. 16S rRNA gene sequence similarity is $95.8 \%$ with M. camini.

The type strain, TFS $10-5^{\mathrm{T}}\left(=\mathrm{JCM} 13303^{\mathrm{T}}=\mathrm{DSM} 17373^{\mathrm{T}}\right)$, was isolated from a sulfide chimney structure at the Yonaguni Knoll IV hydrothermal field, Southern Okinawa Trough $\left(24^{\circ} 50.938^{\prime} \mathrm{N} 122^{\circ} 42.020^{\prime} \mathrm{E}\right)$. 


\section{Acknowledgements}

We would like to thank Dr Katsuyuki Uematsu for assistance in taking electron micrographs. We also express our appreciation to the operation teams of the $R / V$ Yokosuka and Shinkai 6500 for their assistance in collecting samples.

\section{References}

Alain, K., Marteinsson, V. T., Miroshnichenko, M. L., BonchOsmolovskaya, E. A., Prieur, D. \& Birrien, J.-L. (2002). Marinitoga piezophila sp. nov., a rod-shaped thermo-piezophilic bacterium isolated under high hydrostatic pressure from a deep-sea hydrothermal vent. Int J Syst Evol Microbiol 52, 1331-1339.

Balch, W. E., Fox, G. E., Magrum, L. J., Woese, C. R. \& Wolfe, R. S. (1979). Methanogens: reevaluation of a unique biological group. Microbiol Rev 43, 260-296.

Charlou, J. L., Fouquet, Y., Donval, J. P., Auzende, J. M., JeanBaptiste, P., Stievenard, M. \& Michel, S. (1996). Mineral and gas chemistry of hydrothermal fluids on an ultrafast spreading ridge: East Pacific Rise, $17^{\circ}$ to $19^{\circ} \mathrm{S}$ (Naudur cruise, 1993) phase separation processes controlled by volcanic and tectonic activity. J Geophys Res 101, 15899-15919.

Charlou, J. L., Donval, J. P., Douville, E., Jean-Baptiste, P., RadfordKnoery, J., Fouquet, Y., Dapoigny, A. \& Stievenard, M. (2000). Compared geochemical signatures and the evolution of Menez Gwen $\left(37^{\circ} 50^{\prime} \mathrm{N}\right)$ and Lucky Strike $\left(37^{\circ} 17^{\prime} \mathrm{N}\right)$ hydrothermal fluids, south of the Azores Triple Junction on the Mid-Atlantic Ridge. Chem Geol 171, 49-75.

Davey, M. E., Wood, W. A., Key, R., Nakamura, K. \& Stahl, D. (1993). Isolation of three species of Geotoga and Petrotoga: two new genera, representing a new lineage in the bacterial line of descent distantly related to the 'Thermotogales'. Syst Appl Microbiol 16, 191-200.

DeLong, E. F. (1992). Archaea in coastal marine environments. Proc Natl Acad Sci U S A 89, 5685-5689.

Donval, J. P., Charlou, J. L., Douville, E., Knoery, J., Fouquet, Y., Poncevera, E., Jean-Baptiste, P., Stievenard, M., German, C. R. \& other authors (1997). High $\mathrm{H}_{2}$ and $\mathrm{CH}_{4}$ content in hydrothermal fluids from Rainbow site newly sampled at $36^{\circ} 14^{\prime} \mathrm{N}$ on the AMAR segment, Mid-Atlantic Ridge (diving FLORES cruise, July 1997): comparison with other MAR sites. Trans Am Geophys Union 78, Supplement, F832 (abstract).

Huber, R., Langworthy, T. A., König, H., Thomm, M., Woese, C. R., Sleytr, U. B. \& Stetter, K. O. (1986). Thermotoga maritima sp. nov. represents a new genus of uniquely extremely thermophilic eubacteria growing up to $90{ }^{\circ} \mathrm{C}$. Arch Microbiol 144, 324-333.

Huber, R., Woese, C. R., Langworthy, T. A., Fricke, H. \& Stetter, K. O. (1989). Thermosipho africanus gen. nov., represents a new genus of thermophilic eubacteria within the "Thermotogales". Syst Appl Microbiol 12, 32-37.

Konno, U., Tsunogai, U., Nakagawa, F., Nakashima, M., Ishibashi, J., Nunoura, T. \& Nakamura, K. (2006). Liquid $\mathrm{CO}_{2}$ venting on seafloor:
Yonaguni Knoll IV hydrothermal system, Okinawa Trough. Geophys Res Lett 33, L16607. doi:10.1029/2006GL026115

Lane, D. J. (1991). 16S-23S rRNA sequencing. In Nucleic Acid Techniques in Bacterial Systematics, pp. 115-175. Edited by E. Stackebrandt \& M. Goodfellow. Chichester: Wiley.

Lauerer, G., Kristjansson, J. K., Langworthy, T. A., König, H. \& Stetter, K. O. (1986). Methanothermus sociabilis sp. nov., a second species within the Methanothermaceae growing at $97^{\circ} \mathrm{C}$. Syst Appl Microbiol 8, 100-105.

Patel, B. K. C., Morgan, H. W. \& Daniel, R. M. (1985). Fervidobacterium nodosum gen. nov. and spec. nov., a new chemoorganotrophic, caldoactive, anaerobic bacterium. Arch Microbiol 141, 63-69.

Porter, K. G. \& Feig, Y. S. (1980). The use of DAPI for identifying and counting aquatic microflora. Limnol Oceanogr 25, 943-948.

Postec, A., Le Breton, C., Fardeau, M. L., Lesongeur, F., Pignet, P., Querellou, J., Ollivier, B. \& Godfroy, A. (2005). Marinitoga hydrogenitolerans sp. nov., a novel member of the order Thermotogales isolated from a black smoker chimney on the Mid-Atlantic Ridge. Int J Syst Evol Microbiol 55, 1217-1221.

Sako, Y., Takai, K., Ishida, Y., Uchida, A. \& Katayama, Y. (1996). Rhodothermus obamensis sp. nov., a modern lineage of extremely thermophilic marine bacteria. Int J Syst Bacteriol 46, 1099-1104.

Takai, K., Sugai, A., Itoh, T. \& Horikoshi, K. (2000). Palaeococcus ferrophilus gen. nov., sp. nov., a barophilic, hyperthermophilic archaeon from a deep-sea hydrothermal vent chimney. Int J Syst Evol Microbiol 50, 489-500.

Takai, K., Komatsu, T., Inagaki, F. \& Horikoshi, K. (2001). Distribution of archaea in a black smoker chimney structure. Appl Environ Microbiol 67, 3618-3629.

Takai, K., Nakagawa, S., Sako, Y. \& Horikoshi, K. (2003). Balnearium lithotrophicum gen. nov., sp. nov., a novel thermophilic, strictly anaerobic, hydrogen-oxidizing chemolithoautotroph isolated from a black smoker chimney in the Suiyo Seamount hydrothermal system. Int J Syst Evol Microbiol 53, 1947-1954.

Takai, K., Hirayama, H., Nakagawa, T., Suzuki, Y., Nealson, K. H. \& Horikoshi, K. (2005). Lebetimonas acidiphila gen. nov., sp. nov., a novel thermophilic, acidophilic, hydrogen-oxidizing chemolithoautotroph within the 'Epsilonproteobacteria', isolated from a deep-sea hydrothermal fumarole in the Mariana Arc. Int J Syst Evol Microbiol 55, 183-189.

Tamaoka, J. \& Komagata, K. (1984). Determination of DNA base composition by reversed-phase high-performance liquid chromatography. FEMS Microbiol Lett 25, 125-128.

Wery, N., Lesongeur, F., Pignet, P., Derennes, V., CambonBonavita, M. A., Godfroy, A. \& Barbier, G. (2001). Marinitoga camini gen. nov., sp. nov., a rod-shaped bacterium belonging to the order Thermotogales, isolated from a deep-sea hydrothermal vent. Int J Syst Evol Microbiol 51, 495-504.

Zillig, W., Holz, I., Janekovic, D., Klenk, H. P., Imsel, E., Trent, J., Wunderl, S., Forjaz, V. H., Coutinho, R. \& other authors (1990). Hyperthermus butylicus, a hyperthermophilic sulfur-reducing archaebacterium that ferments peptides. J Bacteriol 172, 3959-3965. 